\title{
LABORATORY EVALUATION OF SOME INSECTICIDES AGAINST SUBTERRANEAN TERMITES IN SOIL LAYERS AND ITS RELATION TO THE WATER TABLE.

\author{
Said, A. A. A. ${ }^{1}$; Salwa E. Negm ${ }^{1}$; Y. El-Sebay ${ }^{2}$ and A.R. El- \\ Bassiouny ${ }^{2}$ \\ 1 - Dept. of Pesticide, Fac. of Agric. El-Mansoura University, Egypt. \\ 2 - Dept. of Wood borers and Termite, Plant Protection Research \\ Institute. Dokki, Giza.
}

\begin{abstract}
The obtained results of soil treatments against Psammotermes hypostoms (Desn.), indicated that, the three tested insecticides in different groups; chlorpyrifos, fipronil and cypermethrin were highly toxic in sub-surface layers of treated soil contains particle size of $>850 \mu \mathrm{m}$ more than other particle sizes 425 and $250 \mu \mathrm{m}$, respectively, and the fine soil was more safety to the ground water. Fipronil showed the highly toxic effect, followed by cypermethrin and chlorpyrifos, respectively. In coarse soil cypermethrin showed more toxic than other tested insecticides. The results of chemical determination of insecticides residues, data indicated that chlorpyrifos was more save for water table at all particle sizes followed by cypermethrin, while fipronil was the lower safety one, especially in soil particle sizes of 850 and $425 \mu \mathrm{m}$, respectively. Generally the data of statistical analysis showed significant variations between all tested factors, (insecticides, particle sizes and depths of soil). with the variable, (mortality\%).
\end{abstract}

\section{INTRODUCTION}

Subterranean termite is one of the most social insects distributed all over the world. Sandy termites, $P$. hypostoms (Desn.), in Egypt is very important economic as a subterranean termites which attacks any host contained cellulose; wood, trees, buildings, papers and crops. ...Etc. Egyptian subterranean termites distributed in the Upper, Lower, Eastern desert, Western desert and Oasis of Egypt and are consider the major species in the desert. The present species is capable to adapt with different soil types and environments. Damage caused by sand termites $P$. hypostoma to rural buildings constructed with mud bricks, woodwork in buildings, agricultural crops, books, government records and other stored products containing cellulose and caused highly economic losses affected on the local income. Recently, control measurements were directed to soil treatments to the different infested targets and such methods were affected on the under ground water as a source of water in different Egyptian locations. The present work was conducted to study the effect of soil treatment with chlorpyrifos, fipronil and cypermethrin against $P$. hypostoma in relation to soil particle size at different depths.

\section{MATERIALS AND METHODS}

A. Tested insecticides:

1- Organophosphates group was represented by chlorpyrifos: $O, O$ - diethyl $O$ 3,5,6 - trichloro - 2 - pyridyl phosphorothioate as Dursban.48\% 
Said, A. A. A. et al.

2-Fipronil group was represented by Fipronil: $( \pm)-5-$ amino $-1-(2,6-$ dichloro - á, á, á-trifluoro- $p$-tolyl) - 4 - trifluoromethylsulfinylpyrazole - 3 carbonitrile as Termidor. 5\%

3- Pyrethroids group: was represented by cypermethrin: $(R S)$ - á -cyano-3phenoxybenzyl (1RS,3RS; $1 R S, 3 S R)-3$ - (2,2 - dichlorovinyl) - 2,2 dimethylcyclopropanecarboxylate

Roth: (RS)- á -cyano-3-phenoxybenzyl (1RS)-cis-trans-3-(2,2-dichlorovinyl)2,2-dimethylcyclopropanecarboxylate as Actamethrin $10 \%$.

B. Preparation of soil:

i. Sandy loamy soil samples were collected from The Regional Agriculture Research Station at Ismailia Governorate, $120 \mathrm{~km}$ east of Cairo. The soil samples were taken randomly from the different sites at depth of 30,60 , $90 \mathrm{~cm}$., where the most termite activity was considered to be within that area. Samples of each level were mixed together to represent one homogenized sample of depth and transmitted to Termite Research unit laboratory, Plant Protection Research Institute for preparation.

ii. Soil samples were screened to three-particle sizes 850, 425 and $250 \mu \mathrm{m}$ using USA Standard Testing Sieve (ASTM. E11. Specification). The screening operation was conducted firstly for particle size $850 \mu \mathrm{m}$ followed by $425 \mu \mathrm{m}$ and then $250 \mu \mathrm{m}$, respectively.

iii. Soil samples were soaked for two hours under tap water and washed several times to get rid of organic matter and dirties. The washed soils were distributed on stainless tray for dryness at open air and overturned from time to time for 48 hours and then sterilized in an electric oven at $105^{\circ} \mathrm{C}$ for 24 hours to eliminate the microorganisms' spores and vegetative stages. Samples are kept in plastic containers and placed in deep freezer for the different treatments.

iv. To prepare a concentration of $500 \mathrm{ppm}$ for each insecticide, a volume of $1.04 \mathrm{ml}$ of chlorpyrifos, $10 \mathrm{ml}$ fipronil and $5.0 \mathrm{ml}$ cypermethrin was dissolved in $200 \mathrm{ml}$ acetone.

v. The washed soil was spread on a clean stainless tray at $1 \mathrm{~cm}$ height and sprayed with formulated prepared insecticide to represent $500 \mathrm{ppm} / 1 \mathrm{~kg}$. Treated soil was shacked by electric shaker for 48 hours. Homogenized treated soil was kept at a glass jars inside deep freezer.

C. Insects collection:

The subterranean termites, $P$. hypostoma were collected from Regional Agriculture Research Station, using El-Sebay modified trap, 1991. Termites were separated from the traps and kept at $27 \mathrm{C} \circ \pm 1 \mathrm{C}$. Daily inspection was carried out and eliminated dead or moribund individuals. The healthy workers were used for the insecticides evaluation, El-Sebay, (1993a\&b); El-Bassiouny (2001) and Ahmed (1997 \& 2003).

\section{Experimental technique:}

To study the vertical movement of insecticides in the ground and it's leaching, hundred centimeters long of PVC tube was divided into 10 pieces, represented 10 depths, each measured $10 \mathrm{~cm}$ in length and $2.5 \mathrm{~cm}$ in diameter, and represented $25 \mathrm{gm}$ in volume. The pieces were attached together again by plaster band to give the same previous column. The column was closed from bottom by muslin cloth and fixed with rubber band. All columns were hanged 
into designed wooden stand to keep it vertically. Column was filled with a certain particle size of untreated soil from segment number 2 to segment number 10 . Segment number one was filled with soil treated by $500 \mathrm{ppm}$ from each tested insecticide. Each insecticide was repeated three times according to every particle size, (three sizes of soil particles were chosen; 850, 425 and $250 \mu \mathrm{m}$.). Each column for each soil particle size was replicated five times. 200 $\mathrm{ml}$ of water (average rain fall at Delta region) was leach gradually from the first segment to receive the access of leach water from the last segment through a glass cup. Installed columns were left for 24 hours. Each column was redivided into its marked pieces, hence fore emptied into aluminum dish and left for dryness in open air. $5 \mathrm{gm}$ from each marked segment was placed in a Petridish, and 20 healthy workers of termites were liberated, provided with moistened cardboard. Each treatment for each depth, and control were replicated five times. Mortality percentages were recorded for 7 days.

Another ... grams were sent to determination of insecticide residues in treated soil.

The obtained data was analyzed using Proc ANOVA in SAS (SAS Institute 1988).

\section{E. Residues determination of tested insecticides in treated soil samples:}

The original method of Davis et al. (1993), was used with some modification, and each pesticide was determined separately in the absence of others insecticides. The methods could be concluded as follows:

Three different methods were selected in determination of insecticides, (chlorpyrifos, fipronil and cypermethrin) in soil samples were extracted by the solvents, acetone, dichloromethane and ethyl acetate.

i. Recovery of insecticides residues from the treated soil:

Different solvent systems were used to choose the most suitable and efficient solvent system for extraction of chlorpyrifos, fipronil and cypermethrin from treated soil. These solvent systems were acetone, dichloromethane and ethyl acetate. There ability to extract the tested insecticides successfully was tested by adding the previously mentioned solvents to samples. Blending, cleaning-up and then determining the recovery percentage of the three tested compounds by GLC.

Results are shown in Table (1). Extraction of the tested insecticides from treated soil was tested by three different solvents namely: acetone, dichloromethane and ethyl acetate. The most suitable of which was dichloromethane with $94.0,91.1$ and $90.2 \%$ percent recovery, and ethyl acetate gave $88.3,89$ and $84.3 \%$ while using acetone $85.4,82$ and $85.4 \%$ percent recovery, for chlorpyrifos, fipronil and cypermethrin respectively.

As shown in table (2). Data revealed that, the rate of recoveries by $500 \mathrm{ppm}$ in soil treated with three insecticides and the rates was follow; the replicates of chlorpyrifos recorded 93.0 and $95.0 \%$ with average $94.0 \%$, the fipronil estimated 82.0 and $83.5 \%$ with average $82.75 \%$, and the cypermethrin estimated 86.5 and $91.5 \%$ with average $89.0 \%$. The obtained data of the insecticides residues were corrected according the previously results. 
Said, A. A. A. et al.

Table (1): Recovery results of three solvents for the tested insecticides in treated soil samples.

\begin{tabular}{|c|c|c|c|c|c|c|}
\hline \multirow[t]{2}{*}{ Tested pesticide } & \multirow[t]{2}{*}{ Solvent } & \multicolumn{2}{|c|}{$\begin{array}{c}\text { Recovered } \\
\text { (ppm) } \\
5 \text { ppm }\end{array}$} & \multicolumn{2}{|c|}{$\begin{array}{c}\% \\
\text { Amount } \\
\text { recovered }\end{array}$} & \multirow[t]{2}{*}{$\begin{array}{c}\text { Average } \\
\%\end{array}$} \\
\hline & & R1 & R2 & R1 & R2 & \\
\hline \multirow{3}{*}{ Chlorpyrifos } & Acetone & 4.21 & 4.33 & 84.2 & 86.6 & 85.4 \\
\hline & Dichloromethane & 4.66 & 4.74 & 93.2 & 94.8 & 94.0 \\
\hline & Ethyl acetate & 4.52 & 4.31 & 90.4 & 86.2 & 88.3 \\
\hline \multirow{3}{*}{ Fipronil } & Acetone & 4.15 & 4.22 & 83 & 84 & 82 \\
\hline & \begin{tabular}{|l|} 
Dichloromethane \\
\end{tabular} & 4.65 & 4.46 & 93 & 89.2 & 91.1 \\
\hline & Ethyl acetate & 4.33 & 4.57 & 86.6 & 91.4 & 89 \\
\hline \multirow{3}{*}{ Cypermethrin } & Acetone & 4.33 & 4.21 & 86.6 & 84.2 & 85.4 \\
\hline & Dichloromethane & 4.57 & 4.45 & 91.4 & 89 & 90.2 \\
\hline & Ethyl acetate & 4.22 & 4.21 & 84.4 & 84.2 & 84.3 \\
\hline
\end{tabular}

Table (2): The amount recovered for tested insecticides, in soil treated with 500ppm.

\begin{tabular}{|l|c|c|c|c|c|}
\hline \multirow{2}{*}{ Insecticides } & \multicolumn{2}{|c|}{$\begin{array}{c}\text { Amount recovered } \\
\text { In ppm }\end{array}$} & \multicolumn{2}{c|}{$\begin{array}{c}\text { Recovered } \\
\%\end{array}$} & \multirow{2}{*}{$\begin{array}{c}\text { Average } \\
\%\end{array}$} \\
\cline { 2 - 5 } & R 1 & R2 & R 1 & R2 & \\
\hline Chlorpyrifos & 465 & 475 & 93.0 & $90.0 \%$ & 94 \\
\hline Fipronil & 410 & 417.5 & 82.0 & $83.5 \%$ & 82.75 \\
\hline Cypermethrin & 432.5 & 457.5 & 86.5 & 91.5 & 89 \\
\hline
\end{tabular}

ii. Analysis condition of tested insecticides:

- Chlorpyrifos

Detector: electron capture

Column temperature: $180^{\circ} \mathrm{C}$

Detector temperature: $300^{\circ} \mathrm{C}$

Injection temperature: $250^{\circ} \mathrm{C}$

Column type: $\mathrm{HP}-1(25 \mathrm{~m} \times 0.23 \mathrm{~mm} \times 0.17 \mu \mathrm{m})$

- Fipronil

Detector: electron capture

Column temperature: $200^{\circ} \mathrm{C}$

Detector temperature: $300^{\circ} \mathrm{C}$

Injection temperature: $250^{\circ} \mathrm{C}$

Column type: $\mathrm{HP}-1(25 \mathrm{~m} \times 0.23 \mathrm{~mm} \times 0.17 \mu \mathrm{m})$

- Cypermethrin

Detector: electron capture

Column temperature: $250{ }^{\circ} \mathrm{C}$

Detector temperature: $300^{\circ} \mathrm{C}$

Injection temperature: $270{ }^{\circ} \mathrm{C}$

Column type: HP $-1(25 \mathrm{~m} \times 0.23 \mathrm{~mm} \times 0.17 \mu \mathrm{m})$ 


\section{RESULTS AND DISCUSSION}

The following results clarify the effect of rains or excessive use of water on the soil treated with insecticides chlorpyrifos, fipronil and cypermethrin at different types of soil particle sizes or leaching into water table under ground.

\section{Chlorpyrifos behavior in treated soil:}

As shown in Table (3), showed that, at particle size $850 \mu \mathrm{m}$ complete mortality was obtained after 6 days $(10-40 \mathrm{~cm}$ depth). Mortality percentages were $93,92,91,67,47$, and $31 \%$ at the seventh day at 50,60, 70, 80, 90 and $100 \mathrm{~cm}$ depth, the efficiency of chlorpyrifos in soil and its complete mortality within the upper $40 \mathrm{~cm}$ of treated soil.

Table (3): Mortality percentages of $\boldsymbol{P}$. hypostoma workers exposed to Chlorpyrifos $48 \% \mathrm{EC}$, at three different particle sizes within 7 days.

\begin{tabular}{|c|c|c|c|c|c|c|c|c|c|}
\hline \multirow{2}{*}{$\begin{array}{l}\text { Particle } \\
\text { size }\end{array}$} & \multirow{2}{*}{$\begin{array}{c}\text { Depth in } \\
\text { cm }\end{array}$} & \multicolumn{7}{|c|}{ Mortality \% in days } & \multirow{2}{*}{ Cont. $\%$} \\
\hline & & $\begin{array}{c}1 \\
\text { day }\end{array}$ & $\begin{array}{c}2 \\
\text { days }\end{array}$ & $\begin{array}{c}3 \\
\text { days }\end{array}$ & $\begin{array}{c}4 \\
\text { days }\end{array}$ & $\begin{array}{c}5 \\
\text { days }\end{array}$ & $\begin{array}{c}6 \\
\text { days }\end{array}$ & $\begin{array}{c}7 \\
\text { days }\end{array}$ & \\
\hline \multirow{10}{*}{$850 \mu \mathrm{m}$} & 10 & 79 & 88 & 95 & 98 & 99 & 100 & 100 & 2 \\
\hline & 20 & 71 & 85 & 93 & 97 & 99 & 100 & 100 & 0 \\
\hline & 30 & 74 & 83 & 89 & 94 & 97 & 99 & 100 & 2 \\
\hline & 40 & 53 & 73 & 82 & 92 & 98 & 100 & 100 & 2 \\
\hline & 50 & 52 & 63 & 75 & 82 & 88 & 92 & 93 & 1 \\
\hline & 60 & 47 & 59 & 71 & 81 & 88 & 91 & 92 & 3 \\
\hline & 70 & 38 & 52 & 61 & 73 & 81 & 90 & 91 & 0 \\
\hline & 80 & 33 & 42 & 50 & 58 & 62 & 65 & 67 & 1 \\
\hline & 90 & 21 & 28 & 32 & 37 & 43 & 46 & 47 & 4 \\
\hline & 100 & 13 & 16 & 22 & 26 & 28 & 30 & 31 & 4 \\
\hline \multirow{10}{*}{$425 \mu \mathrm{m}$} & 10 & 87 & 95 & 97 & 100 & 100 & 100 & 100 & 0 \\
\hline & 20 & 83 & 92 & 96 & 98 & 100 & 100 & 100 & 2 \\
\hline & 30 & 73 & 83 & 92 & 95 & 98 & 100 & 100 & 0 \\
\hline & 40 & 54 & 72 & 83 & 92 & 97 & 100 & 100 & 2 \\
\hline & 50 & 56 & 71 & 82 & 88 & 94 & 97 & 98 & 3 \\
\hline & 60 & 45 & 62 & 71 & 77 & 83 & 85 & 85 & 0 \\
\hline & 70 & 45 & 61 & 70 & 79 & 83 & 84 & 85 & 2 \\
\hline & 80 & 38 & 57 & 63 & 67 & 71 & 72 & 72 & 0 \\
\hline & 90 & 21 & 31 & 36 & 40 & 43 & 44 & 44 & 1 \\
\hline & 100 & 6 & 10 & 14 & 15 & 17 & 17 & 17 & 0 \\
\hline \multirow{10}{*}{$250 \mu \mathrm{m}$} & 10 & 87 & 94 & 98 & 100 & 100 & 100 & 100 & 1 \\
\hline & 20 & 76 & 87 & 95 & 99 & 100 & 100 & 100 & 3 \\
\hline & 30 & 69 & 84 & 91 & 96 & 98 & 100 & 100 & 0 \\
\hline & 40 & 62 & 77 & 86 & 90 & 95 & 98 & 100 & 0 \\
\hline & 50 & 56 & 72 & 84 & 93 & 97 & 97 & 97 & 1 \\
\hline & 60 & 51 & 71 & 82 & 88 & 93 & 94 & 94 & 0 \\
\hline & 70 & 36 & 50 & 58 & 66 & 69 & 74 & 74 & 2 \\
\hline & 80 & 18 & 30 & 36 & 39 & 42 & 45 & 45 & 0 \\
\hline & 90 & 8 & 11 & 16 & 17 & 20 & 21 & 21 & 3 \\
\hline & 100 & 7 & 13 & 15 & 18 & 18 & 18 & 18 & 0 \\
\hline
\end{tabular}

At $425 \mu \mathrm{m}$ sizes, $100 \%$ mortality were after 4 days (10 cm depth) 5,6 and 6 days (at 20,30 and $40 \mathrm{~cm}$ depth). While was ranged from $98 \%$ to $17 \%$ between depths of 50 to $100 \mathrm{~cm}$. At $250 \mu \mathrm{m}$ complete mortality were at $10,20,30$, and 
Said, A. A. A. et al.

$40 \mathrm{~cm}$ depth represented fourth, fifth, sixth and seventh days of exposure. While fluctuated between 97 and $18 \%$ in the seventh days at depth from 50 to $100 \mathrm{~cm}$. Chlorpyrifos seems to be very toxic at the first soil layers $(0-40 \mathrm{~cm})$ and gradually decreases downwards. Mortality $\%$ in control recorded at more $4 \%$ for the three tested soil particle sizes.

Singh et al (2000), in India, reported that, Chlorpyrifos, gave the movement of pesticide graded as follow: sandy loam, loam and salty loam soils when the organic matter washing and removal from the soils increased the movement of insecticides and same effect.

Mustafa (1975), mentioned that the movement of dursban are differed depending on the concentration and soil type. The highest of concentration found more downward movement. However, the author reported that dursban amount detected in the soil depth ranged from $(20-25 \mathrm{~cm}$ depth) in loamy sand soil. Residues of dursban were decreased gradually from the first layer and found the least quantities in the layer from $15-20 \mathrm{~cm}$. depth in loamy sand soil.

Data are agree with those of Pike et al (1981), who mentioned that, the residues of Chlorpyrifos was found in the top $2.5 \mathrm{~cm}$ and the vertical movement in the irrigation soil was at least more than $99 \%$.

Also, data are corresponding with Ghoniem (1979), resulted that, loam soil was more adsorption of insecticide allowed by calcareous and sandy loam, also dursban was less adsorption than other tested insecticides and the adsorption degree is increased by increasing of organic matters.

\section{Fipronil behavior in treated soil:}

Data in Tables (4), show the fipronil behavior in different particle size of soils. At $850 \mu \mathrm{m}$ size, complete mortality was obtained after one day of application at $10 \mathrm{~cm}$ depth. After three, six and five days complete mortality were obtained at the depths of $(20$ and 30$),(40$ and $50 \mathrm{~cm})$. While mortality efficiency were $96,84,48,14$, and $8 \%$ at depth of $60,70,80,90$, and $100 \mathrm{~cm}$ respectively. At $425 \mu \mathrm{m}$ particle size complete mortality was recorded at the first day of application at 10 and $20 \mathrm{~cm}$ depth. And reached $100 \%$ at 4,6 and 5 days at depths of 30,40 and $50 \mathrm{~cm}$. While less mortality at $68,39,17,9$ and $0 \%$ were obtained at $60,70,80,90$, and $100 \mathrm{~cm}$ depth. At $250 \mu \mathrm{m}$ particle size complete mortality (100\%), were recorded in the first day at 10 and $20 \mathrm{~cm}$. soil depth and the mortality complete at the third and fifth of 30 and $40 \mathrm{~cm}$. soil depth, and were $94,58,38,21,1$ and $1 \%$ at the depth of 50, 60, 70, 80, 90, and $100 \mathrm{~cm}$.

From the pre-mentioned data it is clear that in the bottom layers the bigger particle size, the higher efficiency of fipronil and vise versa. Fipronil has high toxicity extended from 10 to $60 \mathrm{~cm}$ depth at 850 and $10-50$ in particle size $425 \mu \mathrm{m}$ size. While at $250 \mu \mathrm{m}$ size the behavior was higher efficiency in surface layers extended from 10 to $40 \mathrm{~cm}$. depth. And apparently has no toxicity at the layer from $90-100 \mathrm{~cm}$. On the other hand, data show high efficacy during the first day of application. Mortality percentages in control counted at more $2 \%$ for the three tested soil particle sizes.

Data are agreement with Ahmed (2003), concluded that, Termidor $5 \%$ could be considered more effective at $50 \mathrm{~cm}$ depth where the mortality 
percentages reached $100 \%$ at the 6 days earlier than those the other depths and the periods.

Table (4): Mortality percentages of $\boldsymbol{P}$. hypostoma workers exposed to fipronil $5 \% \mathrm{EC}$, at three different particle sizes within 7 days.

\begin{tabular}{|c|c|c|c|c|c|c|c|c|c|}
\hline \multirow[b]{2}{*}{$\begin{array}{c}\text { Particle } \\
\text { size }\end{array}$} & \multirow[b]{2}{*}{$\begin{array}{c}\text { Depth in } \\
\text { cm }\end{array}$} & \multicolumn{7}{|c|}{ Mortality\% in Days } & \multirow{2}{*}{ Cont.\% } \\
\hline & & $\begin{array}{c}1 \\
\text { day }\end{array}$ & $\begin{array}{c}2 \\
\text { days }\end{array}$ & $\begin{array}{c}3 \\
\text { days }\end{array}$ & $\begin{array}{c}4 \\
\text { days }\end{array}$ & $\begin{array}{c}5 \\
\text { days }\end{array}$ & $\begin{array}{c}6 \\
\text { days }\end{array}$ & $\begin{array}{c}7 \\
\text { days }\end{array}$ & \\
\hline \multirow{10}{*}{$850 \mu \mathrm{m}$} & 10 & 100 & 100 & 100 & 100 & 100 & 100 & 100 & 0 \\
\hline & 20 & 95 & 99 & 100 & 100 & 100 & 100 & 100 & 0 \\
\hline & 30 & 96 & 99 & 100 & 100 & 100 & 100 & 100 & 0 \\
\hline & 40 & 83 & 90 & 94 & 97 & 99 & 100 & 100 & 0 \\
\hline & 50 & 67 & 79 & 89 & 98 & 100 & 100 & 100 & 1 \\
\hline & 60 & 67 & 82 & 89 & 94 & 96 & 96 & 96 & 0 \\
\hline & 70 & 56 & 67 & 78 & 83 & 84 & 84 & 84 & 0 \\
\hline & 80 & 28 & 34 & 42 & 46 & 48 & 48 & 48 & 0 \\
\hline & 90 & 5 & 6 & 13 & 14 & 14 & 14 & 14 & 1 \\
\hline & 100 & 6 & 8 & 8 & 8 & 8 & 8 & 8 & 0 \\
\hline \multirow{10}{*}{$425 \mu \mathrm{m}$} & 10 & 100 & 100 & 100 & 100 & 100 & 100 & 100 & 0 \\
\hline & 20 & 100 & 100 & 100 & 100 & 100 & 100 & 100 & 0 \\
\hline & 30 & 90 & 96 & 99 & 100 & 100 & 100 & 100 & 0 \\
\hline & 40 & 76 & 86 & 94 & 97 & 99 & 100 & 100 & 0 \\
\hline & 50 & 54 & 68 & 78 & 84 & 100 & 100 & 100 & 1 \\
\hline & 60 & 46 & 60 & 66 & 68 & 68 & 68 & 68 & 2 \\
\hline & 70 & 25 & 30 & 36 & 39 & 39 & 39 & 39 & 0 \\
\hline & 80 & 12 & 15 & 17 & 17 & 17 & 17 & 17 & 0 \\
\hline & 90 & 4 & 7 & 9 & 9 & 9 & 9 & 9 & 0 \\
\hline & 100 & 0 & 0 & 0 & 0 & 0 & 0 & 0 & 0 \\
\hline \multirow{10}{*}{$250 \mu \mathrm{m}$} & 10 & 100 & 100 & 100 & 100 & 100 & 100 & 100 & 0 \\
\hline & 20 & 100 & 100 & 100 & 100 & 100 & 100 & 100 & 0 \\
\hline & 30 & 94 & 98 & 100 & 100 & 100 & 100 & 100 & 1 \\
\hline & 40 & 85 & 92 & 97 & 99 & 100 & 100 & 100 & 0 \\
\hline & 50 & 49 & 65 & 71 & 73 & 94 & 94 & 94 & 2 \\
\hline & 60 & 39 & 48 & 53 & 57 & 58 & 58 & 58 & 0 \\
\hline & 70 & 24 & 42 & 35 & 38 & 38 & 38 & 38 & 0 \\
\hline & 80 & 9 & 15 & 20 & 21 & 21 & 21 & 21 & 1 \\
\hline & 90 & 1 & 1 & 1 & 1 & 1 & 1 & 1 & 0 \\
\hline & 100 & 1 & 1 & 1 & 1 & 1 & 1 & 1 & 0 \\
\hline
\end{tabular}

\section{Cypermethrin behavior in treated soil:}

Data presented in Tables (5), show the behavior of cypermethrin and its vertical movements downwards.

At a soil particle size $850 \mu \mathrm{m}, 100 \%$ mortality was obtained after three and four days of exposure, at 20,30 and $40 \mathrm{~cm}$ depth and after 6 and 7 days at 60 and $70 \mathrm{~cm}$ depth, respectively, while, mortality percentages were $79,72,26$ and $21 \%$ in the seventh day at depth of $70,80,90$ and $100 \mathrm{~cm}$, respectively. At $425 \mu \mathrm{m}$ particle size, complete mortality were recorded in the second, third, fourth and sixth day of exposure at depth of $10,20,30$ and $40 \mathrm{~cm}$. The highest mortality was 97 and $96 \%$ at 50 and $60 \mathrm{~cm}$ depth. While the lowest mortality (37 and $15 \%$ ) was occurred at 90 and $100 \mathrm{~cm}$ depth. At $250 \mu \mathrm{m}$ particle size, mortality was $100 \%$ in the first third and fourth day at depth of 10, 20, and $30 \mathrm{~cm}$ respectively. And fluctuated from 97,85 to $81 \%$ at the fifth, sixth and 
Said, A. A. A. et al.

forth day in depth of 40,50 , and $60 \mathrm{~cm}$, respectively. While the lowest one $(7 \%)$ was noticed at $100 \mathrm{~cm}$ depth.

Table (5): Mortality percentages of $\boldsymbol{P}$. hypostoma workers exposed to cypermethrin $10 \% \mathrm{EC}$, at three different particle sizes within 7 days.

\begin{tabular}{|c|c|c|c|c|c|c|c|c|c|}
\hline \multirow{2}{*}{$\begin{array}{l}\text { Particle } \\
\text { size }\end{array}$} & \multirow{2}{*}{$\begin{array}{l}\text { Depth in } \\
\text { cm }\end{array}$} & \multicolumn{7}{|c|}{ Mortality\% in Days } & \multirow{2}{*}{ Cont. $\%$} \\
\hline & & $\begin{array}{c}1 \\
\text { day }\end{array}$ & $\begin{array}{c}2 \\
\text { days }\end{array}$ & $\begin{array}{c}3 \\
\text { days }\end{array}$ & $\begin{array}{c}4 \\
\text { days }\end{array}$ & $\begin{array}{c}5 \\
\text { days }\end{array}$ & $\begin{array}{c}6 \\
\text { days }\end{array}$ & $\begin{array}{c}7 \\
\text { days }\end{array}$ & \\
\hline \multirow{10}{*}{$850 \mu \mathrm{m}$} & 10 & 94 & 99 & 100 & 100 & 100 & 100 & 100 & 1 \\
\hline & 20 & 91 & 98 & 99 & 100 & 100 & 100 & 100 & 0 \\
\hline & 30 & 88 & 95 & 98 & 100 & 100 & 100 & 100 & 0 \\
\hline & 40 & 75 & 91 & 98 & 100 & 100 & 100 & 100 & 0 \\
\hline & 50 & 70 & 84 & 92 & 97 & 99 & 100 & 100 & 1 \\
\hline & 60 & 56 & 79 & 87 & 95 & 99 & 100 & 100 & 2 \\
\hline & 70 & 50 & 67 & 75 & 77 & 78 & 79 & 79 & 1 \\
\hline & 80 & 36 & 51 & 57 & 65 & 69 & 71 & 72 & 0 \\
\hline & 90 & 12 & 18 & 23 & 25 & 26 & 26 & 26 & 1 \\
\hline & 100 & 11 & 17 & 20 & 21 & 21 & 21 & 21 & 0 \\
\hline \multirow{10}{*}{$425 \mu \mathrm{m}$} & 10 & 96 & 100 & 100 & 100 & 100 & 100 & 100 & 1 \\
\hline & 20 & 94 & 96 & 100 & 100 & 100 & 100 & 100 & 0 \\
\hline & 30 & 87 & 93 & 98 & 100 & 100 & 100 & 100 & 0 \\
\hline & 40 & 66 & 80 & 88 & 93 & 97 & 100 & 100 & 0 \\
\hline & 50 & 66 & 76 & 81 & 91 & 94 & 96 & 97 & 0 \\
\hline & 60 & 52 & 71 & 81 & 88 & 92 & 96 & 96 & 2 \\
\hline & 70 & 61 & 72 & 80 & 83 & 85 & 85 & 85 & 1 \\
\hline & 80 & 38 & 59 & 67 & 72 & 74 & 78 & 79 & 0 \\
\hline & 90 & 11 & 22 & 28 & 32 & 36 & 37 & 37 & 0 \\
\hline & 100 & 5 & 13 & 13 & 15 & 15 & 15 & 15 & 1 \\
\hline \multirow{10}{*}{$250 \mu \mathrm{m}$} & 10 & 100 & 100 & 100 & 100 & 100 & 100 & 100 & 0 \\
\hline & 20 & 91 & 96 & 100 & 100 & 100 & 100 & 100 & 1 \\
\hline & 30 & 91 & 96 & 99 & 100 & 100 & 100 & 100 & 1 \\
\hline & 40 & 78 & 88 & 92 & 95 & 97 & 97 & 97 & 0 \\
\hline & 50 & 63 & 75 & 77 & 80 & 83 & 85 & 85 & 0 \\
\hline & 60 & 56 & 61 & 72 & 81 & 81 & 81 & 81 & 0 \\
\hline & 70 & 50 & 54 & 59 & 62 & 64 & 64 & 64 & 0 \\
\hline & 80 & 36 & 38 & 47 & 49 & 50 & 52 & 52 & 2 \\
\hline & 90 & 12 & 18 & 20 & 20 & 21 & 21 & 21 & 0 \\
\hline & 100 & 6 & 7 & 7 & 7 & 7 & 7 & 7 & 1 \\
\hline
\end{tabular}

According to such results, cypermethrin after 7 days of treatment moved downward to $60 \mathrm{~cm}$ and gave mortality $100 \%$ when applied at a soil contains particle size more than $850 \mu \mathrm{m}$ particle size. and gave complete mortality up to $40 \mathrm{~cm}$ depth when applied in soil particles measured $425 \mu \mathrm{m}$, while reached to $30 \mathrm{~cm}$ in soil contains particle less than $250 \mu \mathrm{m}$. The least mortality was reached to the depth between $90-100 \mathrm{~cm}$; $(26-21 \%)$, in particle size $850 \mu \mathrm{m}$; (37-15\%), in particle size $425 \mu \mathrm{m}$; and (21-7\%), in particle size $250 \mu \mathrm{m}$, respectively. Mortality\% in control recorded $2 \%$ at more for all tested soil particle sizes

Tasamouh et al (1983), studied the residues in sandy loam soil of chlorpyrifos. It was only $13.3 \%$ after 16 weeks at 1 ppm, while it was $20.7 \%$ and 21.3 at 10 and $100 \mathrm{ppm}$ respectively. Chlorpyrifos extracted from the treated soil. 
The author tested toxicity of some organic insecticides against termites Psammotermes hypostoma in laboratory. Data showed that the best orders of efficacy for 16 tested insecticides by the applied doses in downward graded as follow: dieldrin, heptinophos, fenvalerate, fenitrothion, primiphose methyl, profenophos, cypermethrin, monocrotophos, chlordane, permethrin, teriazophos, mephospholan, methomyl, diflopenzuron, tetrachlorovenphos and azodrin. The number of termites dead or moribund evaluated after $24 \mathrm{hr}$. LD 50 was estimated from each concentration mortality regression lines.

Data are agree with Abdel-Wahab (1985), mentioned that, the pyrethroids compounds were the most effective ones, followed by chlorinated hydrocarbons and then carbamate and organophosphorus compounds, against Amitermes desertorum in the lab.

Data tabulated in Table (6), show that, chlorpyrifos gave complete mortality in treated soil ranged between $10-40 \mathrm{~cm}$ at all tested particle size. Fipronil gave $100 \%$ mortality at a layer from $10-50 \mathrm{~cm}$ in particle size 850 and $425 \mu \mathrm{m}$, while at $250 \mu \mathrm{m}$ decreased to $10-40 \mathrm{~cm}$ depths. Cypermethrin gave complete mortality till $60 \mathrm{~cm}$ at particle size $850 \mu \mathrm{m}$ and at 425 and $250 \mu \mathrm{m}$ gave the same mortality at $40 \mathrm{~cm}$ depth.

Table (6): Compared differences in the efficiency of three different groups of chemicals against $P$. hypostoma workers relatively to different particle size and depth of soil layers.

\begin{tabular}{|c|c|c|c|c|}
\hline \multirow{2}{*}{$\begin{array}{l}\text { Particle } \\
\text { size }\end{array}$} & \multirow{2}{*}{$\begin{array}{l}\text { Depth } \\
\text { in } \mathbf{c m}\end{array}$} & \multicolumn{3}{|c|}{ Mortality\% after 7 days } \\
\hline & & Chlorpyrifos & Fipronil & Cypermethrin \\
\hline \multirow{10}{*}{$850 \mu \mathrm{m}$} & 10 & 100 & 100 & 100 \\
\hline & 20 & 100 & 100 & 100 \\
\hline & 30 & 100 & 100 & 100 \\
\hline & 40 & 100 & 100 & 100 \\
\hline & 50 & 93 & 100 & 100 \\
\hline & 60 & 92 & 96 & 100 \\
\hline & 70 & 91 & 94 & 79 \\
\hline & 80 & 67 & 48 & 72 \\
\hline & 90 & 47 & 14 & 26 \\
\hline & 100 & 31 & 8 & 21 \\
\hline \multirow{10}{*}{$425 \mu \mathrm{m}$} & 10 & 100 & 100 & 100 \\
\hline & 20 & 100 & 100 & 100 \\
\hline & 30 & 100 & 100 & 100 \\
\hline & 40 & 100 & 100 & 100 \\
\hline & 50 & 98 & 100 & 97 \\
\hline & 60 & 85 & 68 & 96 \\
\hline & 70 & 84 & 39 & 85 \\
\hline & 80 & 72 & 17 & 79 \\
\hline & 90 & 44 & 9 & 37 \\
\hline & 100 & 17 & 0 & 15 \\
\hline \multirow{10}{*}{$250 \mu \mathrm{m}$} & 10 & 100 & 100 & 100 \\
\hline & 20 & 100 & 100 & 100 \\
\hline & 30 & 100 & 100 & 100 \\
\hline & 40 & 98 & 100 & 97 \\
\hline & 50 & 97 & 94 & 85 \\
\hline & 60 & 94 & 58 & 81 \\
\hline & 70 & 74 & 38 & 81 \\
\hline & 80 & 45 & 21 & 64 \\
\hline & 90 & 21 & 1 & 52 \\
\hline & 100 & 20 & 1 & 21 \\
\hline
\end{tabular}


Said, A. A. A. et al.

\section{Chemical determination of tested insecticides residues in treated soil samples:}

Depending on GLC analysis, the results of soil samples representing residues of the three insecticides moved downward into the depth of treated soil.

Data in table (7) show the ppm contents of each chemical through each particle size of soil. the results of soil samples analysis contained the tested chemicals in ppm at soil size $850 \mu \mathrm{m}$. Soil treated with concentration of chlorpyrifos kept its highly doses (908ppm) at the first $10 \mathrm{~cm}$ upper soil level and $60 \mathrm{ppm}$ till $40 \mathrm{~cm}$ depth then decreased to $10 \mathrm{ppm}$ at $100 \mathrm{~cm}$ depth. Fipronil reached a high concentration of $2756.8 \mathrm{ppm}$ at the soil surface, then fluctuated between 81.8 and $834 \mathrm{ppm}$ at 20 and $90 \mathrm{~cm}$ depth and recorded the highest concentration $2847 \mathrm{ppm}$ at $100 \mathrm{~cm}$ depth. Cypermethrin reached to $1182 \mathrm{ppm}$ at the soil surface, $2063 \mathrm{ppm}$ at $40 \mathrm{~cm}$ and decreased all the depth distance.

In soil particle size $425 \mu \mathrm{m}$, chlorpyrifos reached to $43 \mathrm{ppm}$ at $20 \mathrm{~cm}$ depth and decreased within the all depth of soil. Fipronil contained 1072ppm at the surface and increased to $1595 \mathrm{ppm}$ at $50 \mathrm{~cm}$ and then decreased to $62 \mathrm{ppm}$ at $100 \mathrm{~cm}$ depth. Cypermethrin was $4799 \mathrm{ppm}$ at surface of soil, and $1176 \mathrm{ppm}$ at $60 \mathrm{~cm}$ depth, then decreased to $392 \mathrm{ppm}$ at $100 \mathrm{~cm}$.

At $250 \mu \mathrm{m}$ size, chlorpyrifos have its highest concentration $(256 \mathrm{ppm})$ at the surface and decreased all the rest of depth to $12 \mathrm{ppm}$. Concentration of fipronil was $533 \mathrm{ppm}$ at $10 \mathrm{~cm}$ and increased to $1293 \mathrm{ppm}$ at $20 \mathrm{~cm}$ then decreased to $17 \mathrm{ppm}$ at $100 \mathrm{~cm}$ depth. Cypermethrin, was $141 \mathrm{ppm}$ at surface soil, then increased to 490 at $20-30 \mathrm{~cm}$ and reduced to $55 \mathrm{ppm}$ at $100 \mathrm{~cm}$ depth.

Generally, at particle size of $850 \mu \mathrm{m}$, chlorpyrifos gave highly ppm contents at $10 \mathrm{~cm}$ depth and decreased at all the rest of depth levels. Fipronil, showed high content of concentration values in the $10 \mathrm{~cm}$ at surface and bottom and with moderate toxicity in med layers. It showed that it may migrate to the lower levels. Soil treated with cypermethrin showed high contents of ppm more than 1000ppm from surface to $30 \mathrm{~cm}$ depth and increased more in the median layers then decreased at the distance of $100 \mathrm{~cm}$ depth. At particle size $425 \mu \mathrm{m}$ chlorpyrifos, increased in toxicity within $20 \mathrm{~cm}$ of upper layer and then reduced to all followed depth as in $850 \mu \mathrm{m}$ size Fipronil, increased within 30$50 \mathrm{~cm}$ depths more than the upper and lower layers. Cypermethrin was more toxic within $40 \mathrm{~cm}$ and decreased at the lower layers. At particle size $250 \mu \mathrm{m}$, chlorpyrifos gave the same behavior of the two particle sizes of 850 and $425 \mu \mathrm{m}$. Fipronil showed high concentration at surface layers $10-20 \mathrm{~cm}$ depth, and then decreased in bottom layers. Cypermethrin was low concentrate at upper layer and increased within $20-60 \mathrm{~cm}$, then reduced its ppm at the lower layer.

From the previously data it could be concluded that, the three tested insecticides were more toxic in sub-surface layers of treated soil with the coarse soil but the treated fine soil were more safety toxicity to the ground water. Fipronil showed to be the highest toxic one, followed by cypermethrin and chlorpyrifos, respectively, in spite of the cypermethrin showed to be the more toxic with coarse soil.

The soil analysis resulted that the chlorpyrifos was the more save for water table at all particle sizes followed by cypermethrin, while fipronil was the 
lower safety one for water table, especially in soil particle sizes 580 and $425 \mu \mathrm{m}$, respectively.

There for accordingly, It could be suggested that, the use of chlorpyrifos seem to be save for water table, due to its occupation the higher layer of soil. In contrary, fipronil gave high toxicity in all depths of treated soil and reached the lower layer of soil. That gives warning about water table. It can use at less doses to get more safe. Cypermethrin gave high toxicity at the med layer of treated soil, while was less toxic at the depth of $90 \mathrm{~cm}$ and lower.

Table (7): Values in ppm of chemical determination for tested insecticides residues in treated soils leached on the untreated soil column through different particle sizes as a long-tube.

\begin{tabular}{|c|c|c|c|c|c|c|c|}
\hline \multirow{3}{*}{$\begin{array}{l}\mathrm{Size} / \mu \\
\mathrm{m}\end{array}$} & \multirow{3}{*}{$\begin{array}{l}\text { Depth } \\
\text { in } \mathbf{c m}\end{array}$} & \multicolumn{6}{|c|}{ Insecticides residues values in ppm } \\
\hline & & \multicolumn{2}{|c|}{ Chlorpyrifos } & \multicolumn{2}{|l|}{ Fipronil } & \multicolumn{2}{|c|}{ Cypermethrin } \\
\hline & & Amount & $\begin{array}{l}\text { Correct } \\
\text { Value }\end{array}$ & Amount & $\begin{array}{l}\text { Correct } \\
\text { Value }\end{array}$ & Amount & $\begin{array}{l}\text { Correct } \\
\text { Value }\end{array}$ \\
\hline \multirow{10}{*}{$850 \mu \mathrm{m}$} & 10 & 854.3 & 908.8 & 2281.3 & 2756.8 & 1052.0 & 1182.0 \\
\hline & 20 & 54.2 & 57.7 & 690.2 & 834.0 & 1106.0 & 1242.7 \\
\hline & 30 & 20.9 & 22.3 & 101.3 & 122.4 & 942.5 & 1058.9 \\
\hline & 40 & 58.36 & 62.085 & 363.5 & 439.274 & 1836.5 & 2063.5 \\
\hline & 50 & 8.5 & 9.0 & 104.8 & 126.7 & 430.0 & 483.1 \\
\hline & 60 & 0.9 & 0.9 & 364.1 & 440 & 229.0 & 257.3 \\
\hline & 70 & 1.5 & 1.6 & 199.3 & 240.8 & 199.5 & 224.2 \\
\hline & 80 & 6.8 & 7.3 & 541.3 & 654.1 & 90.5 & 101.7 \\
\hline & 90 & 6.9 & 7.4 & 67.8 & 81.8 & 122.5 & 137.6 \\
\hline & 100 & 9.5 & 10.1 & 2356.5 & 2847.7 & 125.0 & 140.4 \\
\hline \multirow{10}{*}{$425 \mu \mathrm{m}$} & 10 & 14.2 & 15.1 & 887.0 & 1071.9 & 4271.5 & 4799.3 \\
\hline & 20 & 41.1 & 43.7 & 556.1 & 671.9 & 2598.5 & 2919.6 \\
\hline & 30 & 2.1 & 2.1 & 105.4 & 127.4 & 1739.0 & 1953.9 \\
\hline & 40 & 3.5 & 3.8 & 967.7 & 1169.4 & 1029.0 & 1156.1 \\
\hline & 50 & 0.7 & 0.7 & 1320.0 & 1595.1 & 1103.5 & 1239.8 \\
\hline & 60 & 1.1 & 1.2 & 36.0 & 43.5 & 1047.5 & 1176.9 \\
\hline & 70 & 0.3 & 0.3 & 84.5 & 102.1 & 363.5 & 408.4 \\
\hline & 80 & 2.6 & 2.7 & 60.0 & 72.5 & 105.0 & 117.9 \\
\hline & 90 & 4.6 & 4.9 & 98.25 & 118.7 & 325.0 & 365.1 \\
\hline & 100 & 1.4 & 1.5 & 51.8 & 62.5 & 349.0 & 392.1 \\
\hline \multirow{10}{*}{$250 \mu \mathrm{m}$} & 10 & 241.4 & 256.8 & 441.4 & 533.4 & 125.5 & 141.0 \\
\hline & 20 & 29.5 & 31.3 & 1075.3 & 1299.4 & 429.0 & 482.0 \\
\hline & 30 & 1.3 & 1.4 & 157.3 & 211.9 & 444.0 & 498.8 \\
\hline & 40 & 1.0 & 1.1 & 191.4 & 231.3 & 238.2 & 267.6 \\
\hline & 50 & 1.2 & 1.3 & 45.7 & 55.2 & 190.5 & 214.0 \\
\hline & 60 & 1.3 & 1.4 & 53.1 & 64.1 & 263.0 & 295.5 \\
\hline & 70 & 15.7 & 16.7 & 57.7 & 69.7 & 56.3 & 63.2 \\
\hline & 80 & 0.4 & 0.4 & 14.1 & 17.0 & 463.0 & 52.2 \\
\hline & 90 & 0.5 & 0.6 & 13.8 & 16.6 & 23.5 & 26.4 \\
\hline & 100 & 11.9 & 12.6 & 109.2 & 131.9 & 49.3 & 55.4 \\
\hline
\end{tabular}

\section{Statistics analysis:}

Data in table (8), clarified that, the mean of treatments for chlorpyrifos, fipronil and cypermethrin, were $79.000,66.867$ and 79.600 respectively, and found significantly differences (F. value 13.29). Also the means of particle sizes were $79.300,74.733$ and 71.433 for particle size 850,425 and $250 \mu \mathrm{m}$ 
Said, A. A. A. et al.

respectively, and $\mathrm{F}$. value recorded significantly 4.02 . The mean's depths were $100,100,100,99.4,96,85.556,73.889,53.889,27.889$ and 14.889 for depths $10,20,30,40,50,60,70,80,90$ and $100 \mathrm{~cm}$ respectively, and $F$. value recorded significantly 79.8 .

Table (8): Illustration of significantly variables between the tested factors, insecticides, particle sizes and depths with the variable factor (mortality\%).

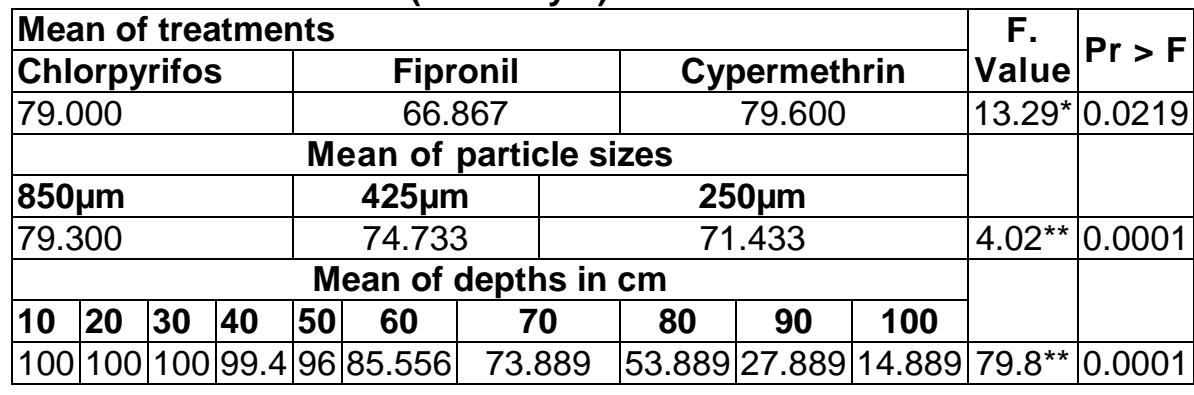

\section{REFERENCES}

Abdel-Wahab m. Ali, M. F. Abo-Ghadir F. M. khalil and N. M. Abdel-Hafez. (1985): Susceptability of Amitermes desertorum Desn. to some organic insecticides. Assiut Journal of Agricaltureal sciences, Vol. 16 (2): 123130.

Ahmed, H. M. (1997): Ecological studies and control of harvester subterranean termite, Anacanthotermes ochracious (Burm.), at Fayoum Gov. M.Sc.Thesis Cairo University, Fayoum. PP. 66.

(2003): Ecological and control studies on Cairo subterranean termites under Fayoum conditions Ph.D degree Thesis University, Fayoum. PP. $127-128$.

Davis, R. W.; Kamble, S. T. and Tolley, M. P. (1993): Microencapsulated Chlorpyrifos distribution in loamy sand and silty clay loam soils when applied with a sub-slab injector for subterranean termites control. Bull. Environ. Contam. Toxicol., 50: 458-465.

El-Bassiouny, A. R. (2001): A study on the ecology and biological control of subterranean termites M. Sc. Thesis, Fac. Agric. Al-Azhar Univ. 145 p.

El-Sebay, Y. (1991): A modified trap for El-Sebay subterranean termites. Fourth Arab Cong. of Plant Protection, Cairo, 1-5 Dec. 1991.

(1993a): Ecological studies on the colony of the harvester termite, A. ochraceus (Burm.) in Egypt. Bull. Soc. Ent. Egypt, Econ. Ser., 20: 1-9.

(1993b): Ecological studies on the subterranean termites harvester A. ochraceus (Burm.) in Egypt. Assuit J. Agric. Sci., 24 (4): 35-47.

Ghoniem A. (1979): Behavior of some insecticides in soil and plant. Ph.D.Thesis, Cairo University pp. 7, 8, 9 and 10.

Mustafa, T. M. (1975): Studies on the residues of some organophosphate and carbamate pesticides. M Sc. Thesis, Fac. Agric. Alexandria Univ. 
Pike, K. S. and Getzin, L. W. (1981): Persistence and movement of Chloropyrophos in spenkler irrigated soil. J. Econ. Entomol.,74: 385388.

SAS Institute (1988), SAS user's guide: Statistics. SAS Institute, Cary, N.C.

Singh, R. P.; Raj, K. and Kumar, R. (2000): Effect of water flux, organic matter, ph and cosolvents on the movement of pesticides in three soils. J. Indian society of soil Sci., 48 (1): 43-51.

Tasamouh K. and M. M. A. Rizk (1983): Laboratory evaluation of the toxicity of some organic insecticides against the subterranean termites Psammotermes spp (Dsneux) Assiut J. of Agic. Sci. 14 (2): 107-112

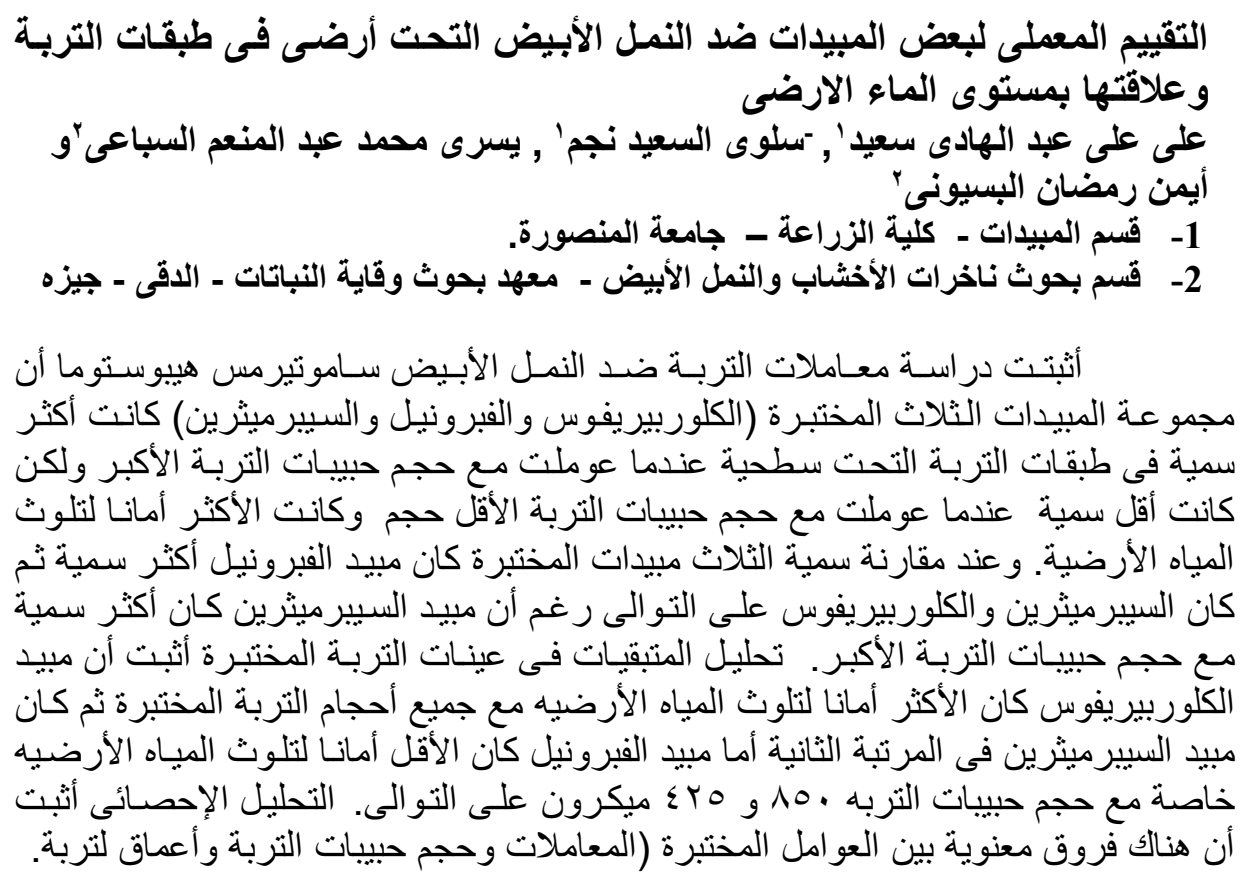

